\title{
ON MALAYAN TENDIPEDINAE I
}

\author{
BY \\ G. KRUSEMAN JR. \\ Zoological Museum, Amsterdam \\ (1 $2^{\text {th }}$ Communication on Tendipedidae)
}

In the Zoological Museum at Amsterdam is a small collection of Tendipedidae from the Netherlands Indies. This paper deals with specimens collected in Java and Sumatra.

\section{TENDIPES JAVANICUS Kieff.}

There are many specimens of this species in the Zoological Museum. But with a few exceptions they differ in colour from the specimens described by KiefFer and Johiannsen. The colour is yellow, scutelstripes and scutellum vittate, abdomen with a brown spot on each tergite. Only some just emerged specimens, in which the heads are shrunk, are bright green without dark spots on the abdomen. Hypopygium, tarsus, A.R. and L.R. are exactly as described by KiEFFer and Johannsen. I think the specimens of these authors were perhaps somewhat immature. Palpi see fig. $I$; antennae of $q$ see fig. 2.

Java: Semarang $6 \sigma^{7} \sigma^{\pi}$ and 3 우 leg. E. JACoBson; Batavia 22. IX. 1936 leg. J. Westenberg ( $\sigma^{\nwarrow}$ ); Tjilengsar i6-ig VI I937 leg J. Westenberg many $\sigma^{\top} \sigma^{\prime \prime}$ and 우.

\section{TENDIPES COSTATUS Joh.}

Joints of palpi see fig. 3 ; antennae of $९$ see fig. 4.

Semarang leg. E. Jacobson $50^{7} \sigma^{\prime}$ and 5 Q $Q$.

\section{SUBGENERA CRYPTOCHIRONOMUS, PARACHIRONOMUS AND HAR- NISCHIA.}

From the Oriental region the males of the following species, belonging to the group of subgenera with reduced appendages, are known:

$\begin{array}{clll}\text { T. Cryptochironomus javae Kieff. 1924 } & \text { A.R. 2,5 } & \text { L.R. I,8 } \\ - & \text { apicalis Kieff. 1924 } & \text { A.R. ? } & \text { L.R. ? } \\ - & \text { polius Kieff. 191 I } & \text { A.R. nearly 2 } & \text { L.R. 2 } \\ - & \text { nudiforceps Kieff. 1922/23 } & \text { A.R. 2,5 } & \text { L.R. I,75 } \\ - & \text { distractus Joh. 1932 } & \text { A.R. I,5 } & \text { L.R. I,8 } \\ \text { T. Parachironomus lacteipennis Kieff. 1921 } & \text { A.R. 2 } & \text { L.R. nearly 2 } \\ - & \text { chlorostolus Kieff. 1912 } & \text { A.R. 2,5 } & \text { L.R. I,3 } \\ - & \text { viridiclava Kieff. 1922/23 } & \text { A.R. 2 } & \text { L.R. I,5 } \\ - & \text { primitivus Joh. I932 } & \text { A.R. over I,8 } & \text { L.R. I,67 }\end{array}$




$\begin{array}{clll}\text { T. Harnischia } & \text { Wcslenbergi nov. sp. } & \text { A.R. } 2 & \text { I.R. 2,7 } \\ \text { T. Suhg. ? } & \text { atrophus Kieff. 1913 } & \text { A.R. } 3 & \text { I.R. 2 } \\ \text {-- } & \text { orissae Kieff. 1913 } & \text { A.R. 2à } 3 & \text { L.R. 2 }\end{array}$

Tendipes viridiclava Kieff. and $T$. primitivus Joh. are probably very nearly related. It is possible, that they will prove to be cospecific.

\section{KEY TO THE ORIENTAL SPECIES}

I Fore tarsi with a beard; A.R. 3 ; L.R. 2 ; Hypopygium vid. fig. 5 atrophus Kieff.

- Fore tarsi without a beard . . . . . . . . . . . . . . . . 2

2 Dististyles straight and pointed . . . . . . . . . . . . . 3

- Dististyles differently formed . . . . . . . . . . . . . . . 4

3 A.R. 2 à 3 ; L.R. 2 ; dististyles $5 \times$ longer than broad . . . orissae Kieff.

- A.R. nearly 2 ; L.R. 2 ; Hypopygium vid. fig. 7 . . . . . . polius Kieff.

- A.R. 2,5 ; L.R. I,75; Hypopygium as in T imberbipes Kieff.

4. Appendages I and 2 well developed, vid. fig. 6; A.R. 2,5 L.R. I,3

nudiforceps Kieff. chlorostolus Kieff.

- Appendages I $\frac{\text { and }}{\text { or }} 2$ smaller or absent . . . . . . . . . . . . . 5

5 Dististyles on the inner side with a hump. Hypopygium vid. fig. 8 . . . 6

- Dististyles without a hump . . ... . . . . . . . . . . . 7

6 F-cu scarcely before rm; A.R. 2 ; L.R. I,5 . . . . . . viridiclava Kieff.

- F-cu distinctly before rm; A.R. more than I,8; L.R. I,67 . primitivus Joh.

7 Dististyles short and thick, scarcely narrowed at tip; A.R. 2,5 jav'ae Kieff.

- Dististyles differently formed . . . . . . . . . . . . . . . 8

8 Appendages 1 and 2 absent, vid. fig. Io . . . . Westenbergi nov. spec.

- Appendage I small and rod-like; ap. 2 absent . . . . lacteipennis Kieff.

- Appendage I bilobed; ap. 2 very much reduced . . . . . apicalis Kieff.

- There is only one hairy appendage (ap. 2?) vid. fig. 9. . . distractus Joh.

TENDIPES (PARACHIR.) PRIMITIVUS Joh.

Semarang II-III Ig06 I ơ leg E. JACOBSON.

TENDIPES (HARNISCHIA) WESTENBERGI nov. spec.

A.R. 2 ; L.R. 2,7. Green, scutelstripes and scutellum vittate. Legs pale, base of metatarsus whitish, last joint of the middle tarsus dark, palpes dark brown, probably the last joint very short, but in the holotype not well preserved. Hypopygium fig. Io. There is no visible separation between basistylus and dististylus. Appendages absent.

Holotype I $\sigma^{7}$; T jilengsar, West Java, I6-I9 VI I937 leg. J. W'Estenberg; in my collection.

POLYPEDILUM PULCHRIPES de Meij. (Chironomus pulchripes de Meij.)

To Prof. de Meijere's description of Chironomus pulchripes-some details, 


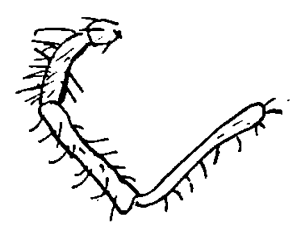

Fig. I

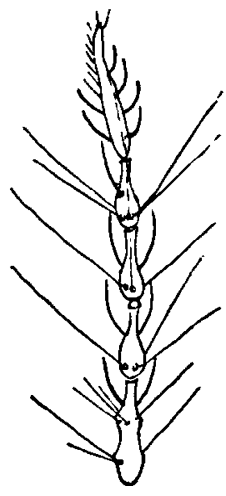

Fig. 2

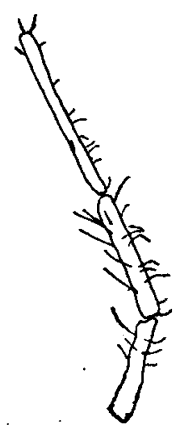

Fig. 3

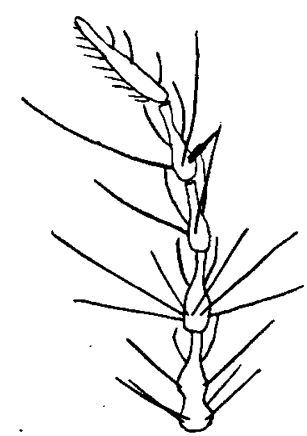

Fig. 4

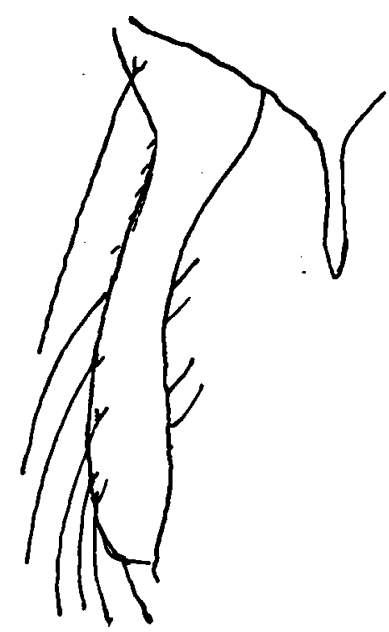

Fig. 5

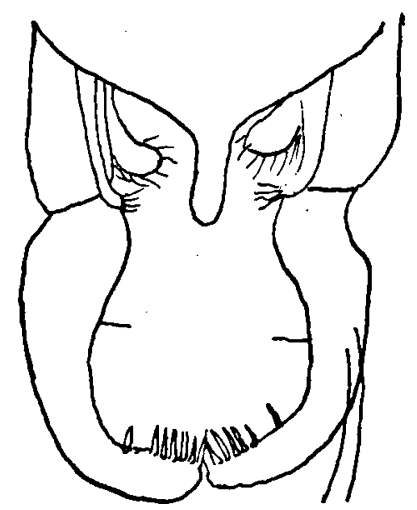

Fig. 6

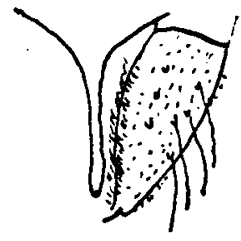

Fig. 7

Fig. I-2 T. javanicus Kieff. palpus and $\&$.antenna; fig. 3-4 T. costatus Joh. palpus and $q$ antenna; fig. 5 T. atrophus Kieff.; fig. 6 T. chlorostolus Kieff.; fig. 7 T. polius Kieff. (Figs. 5, 6, 7 copied from Kieffer). 


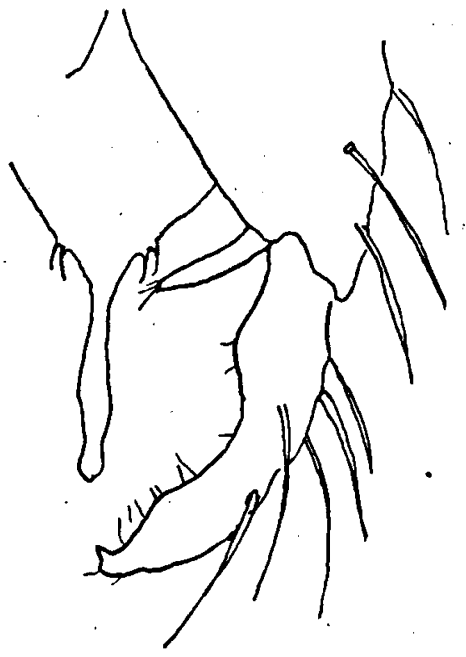

Fig. 8

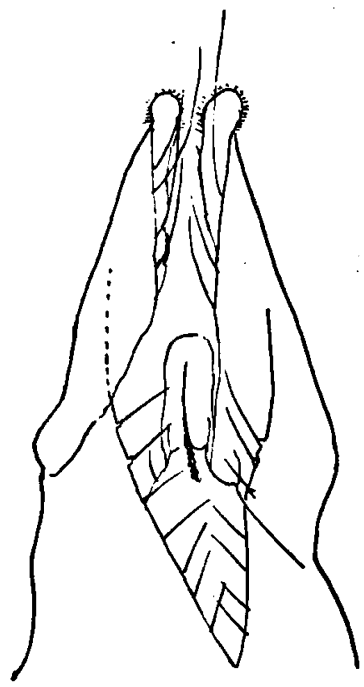

Fig. 10

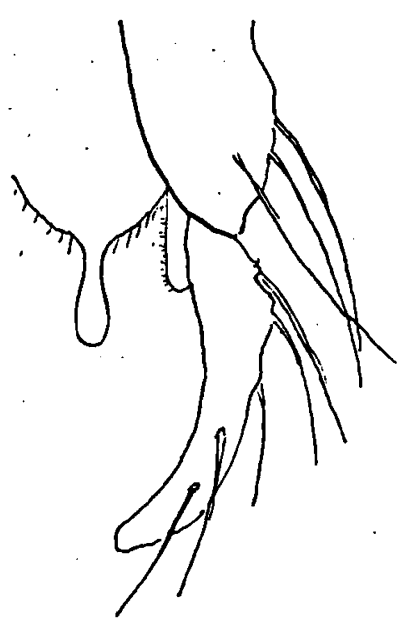

Fig. 9

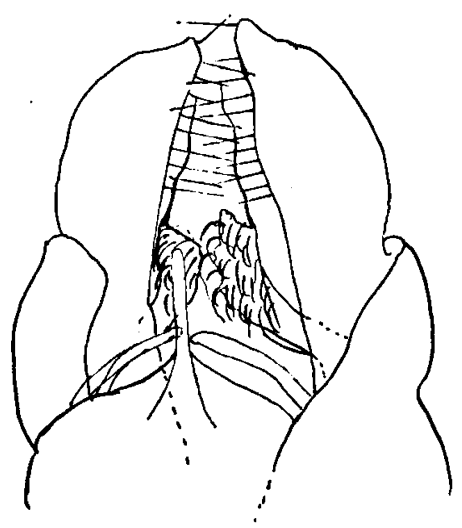

Fig. II

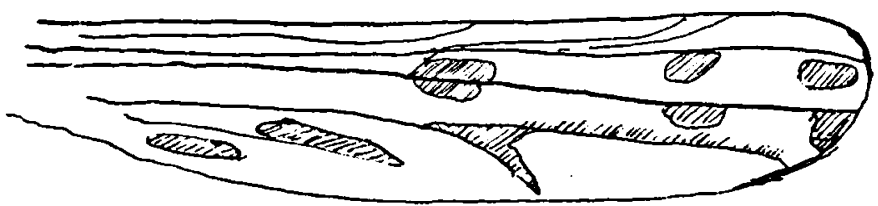

Fig. 12

Fig. 8 T. primitivus Joh.; fig. 9 T. distractus Joh.; fig. Io T. Westenbergi nov. spec.; fig. II-I2 P. javanum nov. spec. Hypopygium and wing (Figs. $8-9$ copied from Johannsen). 
necessary to determine the systematic position of this conspicuous species, should be added:

Small comb of hind tibiae with a spur; large comb unarmed. Palpes consist of four joints; scutum without hump in the middle; An slightly curved downward near tip; F-cu before rm; A.R. I,I ; L.R. 0,8-0,9; distance between the eyes slightly less than half the eye-length. Pulvilli have the normal form (vide EDWARDS 1929 page 40I).

Length $6,5 \mathrm{~mm}$; wing $4,7 \mathrm{~mm}$, iridescent, veins $\sigma^{7} \sigma^{7}$ yellowish, in $\$$ brown; rm dark brown; halteres with a dark knob.

Sumatra: Sandaran agung VII I9I5 $20^{\prime} \sigma^{\prime}$ and VIII I9I5 $\sigma^{\circ}$ and $Q$ leg. E. Jacobson.

POLYPEDILUM JAVANUM nov. spec.

ऽ. Dark brown species, mesonotum slightly prunose; legs pale, fore and middle femora darker; last joints of all tarsi brown, fore tarsi with slight beard. Hypopygium brown; vid. fig. I I. A.R. about 3,4 ; L.R. I,4. Wings with 9 iridescent spots; vid. fig. I2.

Q. Quite the same in colour. The joints $3-5$ of the antennae bottle-shaped, 2nd joint not attenuated in the middle.

This species differs from P. ceylanicus Kieff. by the bottle-shaped joints of the $Q$ antennae, in P. ceylanicus they are "fusiforme".

P. pelostolum Kieff. can be distinguished from P. javanum by the A.R. 2,5 and the leg ratio "vorderer Metatarsus etwas länger als die Tibia".

P. javanum can be placed in Johannsen's key under 7. Legs pale, fore and middle femora darker, last 2 joints of the tarsi brown. A.R. 3,4. Holotype ơ, allotype $\$$ : Java Tjilengsar I6-I9 VI I936 leg J. Westenberg. 